\title{
To be or not to be a technical university: organisational categories as reference points in higher education
}

\author{
Lars Geschwind $^{1}$ (iD) - Anders Broström ${ }^{2}$ (iD \\ Accepted: 23 August 2021/ Published online: 9 September 2021 \\ (C) The Author(s) 2021
}

\begin{abstract}
Classifications of higher education institutions into categories that are more or less clearly differentiated through prestige and status are legion in the world of higher education. The notion of parallel categories with comparable statuses, such as those of different types of universities, is however much less well understood. This paper investigates how universities navigate between such alternative categories. We examine boundary work and institutional change involving Swedish higher education institutions with significant activity in engineering sciences in order to analyse how actors relate to ideas regarding the category 'technical university' as an ideal potentially distinct from that of the broad, comprehensive university. Analysis of two cases in the second half of the twentieth century shows that for engineering faculty, a focused technical university was an attractive alternative to the institutional model of the broad university. In contrast, analysis of two twenty-first-century cases suggests that aspirations to be recognised as a technical university were largely driven by adaption to external stakeholders' interests. We discuss these findings in light of the emergence of the global hegemonic category 'research university'. We also suggest that the organisational identity of a HEI may be tied to ideas about an organisational category through imprinting and path dependency. Moreover, we propose that changes over time in how categories are perceived may serve as an impetus to organisational change.
\end{abstract}

Keywords Technical universities · Organisational identity $\cdot$ History $\cdot$ Identity formation · Rhetoric $\cdot$ Categories

Anders Broström

andbr@kth.se

1 Department of Learning in Engineering Sciences, KTH Royal Institute of Technology, Stockholm, Sweden

2 Department of Industrial Economics and Management, KTH Royal Institute of Technology, Stockholm, Sweden 


\section{Introduction}

Higher education landscapes worldwide are populated with institutions featuring significant differences in terms of their history, size, disciplinary scope, and research funding. In view of such heterogeneity, clustering higher education institutions (HEIs) into categories of one sort or another is a natural response. Extant work has acknowledged the existence of organisational categories within the higher education landscape to which individual HEIs may adhere (Teichler 1988; Fumasoli and Huisman 2013). Some such systems of categories are formalised and linked to different national funding mechanisms (Kyvik 2008), 'clubs' with closed memberships or widely recognised classifications, such as the Carnegie classification (van Vught 2009). Others are informal, linked to rankings (Meyer et al. 2017), institutional reputation (Paradeise and Thoenig 2013), or widely used category labels such as research university (Pelikan 1992).

However, most studies that consider categories, groups, or classifications of HEIs essentially discuss a mono-dimensional, status-based differentiation (Moodie 2009; Brankovic 2018) connected to institutional prestige (Eckel 2008). A few studies have provided more elaborate schemes, where the positioning of individual HEIs is considered in terms of both horizontal (i.e. status and prestige) and vertical differentiation (Bleiklie 2005; Teichler 2008). According to Bleiklie (2005), the latter dimension captures 'categories differentiated by specialisation'. Such specialisation is typically defined through close connections to a profession and/or a specific sector such as agriculture, business, medicine, theology, and technology and engineering. Studies of HEIs have occasionally also chosen a specific category for the object of study, such as investigations by Bennis and O'Toole (2005) and Augier and March (2011) that focused on business schools. However, such work has largely taken these categories of horizontal differentiation - and individual HEIs' positioning within these categories - as given. The literature is largely silent on how HEIs navigate between horizontally differentiated categories as well as how and why the attractiveness of category membership may shift over time. Thus, the problem that we seek to investigate in this paper concerns whether an HEI might have an interest in placing itself in the organisational category 'technical university' at different historical conjunctures and why it might choose to do so. The relevant alternative in this case (as well as for all specialised HEI categories) is not another type of specialisation altogether but rather adherence to an organisational category characterised by a lower degree of disciplinary specialisation.

We theorise that identification, institutional comparison, and alignment with organisational categories provide orientation and self-understanding while also recognising that organisations may navigate opportunistically between horizontally differentiated categories to gain advantages among different external stakeholder groups. This lens is applied to a historical study of how Swedish HEIs have related to available organisational categories during times of disruption and possible change. In a study of boundary negotiation processes involving Swedish HEIs where engineering science plays an important role, we investigate how ideas about the category 'technical university' are mobilised (and, respectively, not mobilised) by key actors. In a cross-case analysis, we consider what makes it attractive for a Swedish HEI to adhere to the category 'technical university'.

Our analysis identifies two types of relationships to external audiences for which it has been considered beneficial to orient an organisation towards this category. The first involves an audience of prospective students believed to associate the professional label 'civilingenjör' with the organisational category 'technical university'. Second, aspirations to be perceived as a 
'technical university' were considered useful in negotiations with the national government and central authorities concerning the allocation of funds and degree awarding rights. Our analysis also identifies how the weakening of both types of logic in the late 2000 s and onwards seems to make the category less relevant among aspiring HEIs - although not necessarily so for the two national champion 'technical universities'. We conclude by noting that the broad research university has reached a status of 'hegemonic category' among contemporary HEIs. Nevertheless, significant heterogeneity remains in terms of disciplinary profiles and organisational identity. Through this analysis, the paper contributes to the understanding of the conditions for specialisation and profiling of HEIs. Furthermore, we suggest that higher education may benefit from more seriously considering the interplay between categories of HEIs as defined through both horizontal and vertical differentiation. By considering how ideas about organisational categories shape the rhetorical and strategic action of HEIs, higher education scholars may gain important insights into how organisational identities are formed, challenged, and reformed.

\section{Organisational categories and organisational identity}

The fundamental observation behind research on the categorisation of organisations is that similarities with other (contemporary or historical) organisations are, in many contexts, essential for maintaining legitimacy and enhancing resource acquisitions (Porac et al. 1989; Deephouse 1999). Categories are generally conceptualised as cognitive constructs that communicate and reinforce the expectations that members and external stakeholders share regarding the properties of member organisations (Metzger 2012). As such, categories both enable and restrain organisational behaviour. For example, an organisation's position within a system of categories affects how external stakeholders evaluate the organisation. In noteworthy contributions, Zuckerman (1999) examined how the classification of firms in the Standard Industrial Classification nomenclature affected their evaluation by investment analysts, and Rao et al. (2005) studied how the two categories 'classical' and 'nouvelle' among French restaurants influenced evaluations by the Guide Rouge ('Michelin Guide').

The literature on categorisation has generated useful insights into how organisations navigate between categorisations and seek their unique identity and position within them (Vergne and Wry 2014). However, as Negro et al. (2010) point out, very few studies have explicitly examined the categories themselves in terms of their emergence, reification, and eventual obsolescence. In particular, scholarly attention has focused on how categorisations affect organisations, largely ignoring questions about how a specific organisation's development of organisational identity relates to the available organisational categories. In most studies discussing organisational categories, the categories themselves are seen as largely exogenous to the actors in the focus of analysis, e.g. because categories follow from an established classification.

In this study, we are interested in a conceptualisation that allows theoretical endogenisation of the system of categories, i.e. where organisations' orientation to different categories and the interpretation of the categories themselves are subject to negotiation. This implies that we think of categories as being defined in relation to other categories. Two properties of organisational categories are central to our theory. First, we conceive of a category as being distinguished from other competing, opposing, or (partly) overlapping categories by virtue of the attributes associated with that category. Attributes are key activities and characteristics 'typical' of 
organisations in the category. Second, a category is associated with a particular status, with certain categories enjoying higher status than others. Organisations acquire legitimacy by conforming and actively adhering to a category enjoying high status within a relevant community. We may refer to a high-status and a low-status category as being vertically differentiated. In analogue, two categories with equivalent status, separated by the attributes associated with them, may be referred to as being horizontally differentiated.

The kinship between categories can be described as an overlap in attributes and in terms of hereditary relationships between general categories and sub-categories. The category 'technical university', for example, is related to the categories 'university' and 'technical education institutions'. However, these relationships are not fixed; different individuals or groups of audiences may hold rather different views of how these relationships are constituted. Associations to attributes and perceptions of status may also change substantially over time as a consequence of renegotiations. Still, both types of association can be expected to be subject to considerable inertia since the renegotiation of a category plays out over a complex, interwoven network of relationships that generally spans national borders and periods of time. Ideas about a category may also be upheld over time through the mimetic influence of leading institutions that are associated with the category.

Our view of organisational categories as distinguished by associations to particular attributes entails that it is natural to consider an organisation's relationship to a category in light of organisational identity (Gioia et al. 2013; Stensaker 2004). An organisation's identity may be strongly connected to aspirations towards inclusion in a particular category. In such a case, the organisation is likely to take action to increase or preserve alignment with core category attributes while avoiding or resisting actions that are perceived as unaligned with those attributes (Glynn and Navis 2013). This type of strong linkages between organisational identity and an organisational category can emerge from - or be strengthened by - external expectations that the organisation will behave in line with a category, i.e. emphasise and leverage category attributes in its strategic development (Koch 2011). Such lock-in effects may create significant institutional inertia, making it difficult for an organisation to respond to changes (Schreyögg et al. 2011).

A category may constitute an important reference point for strategic action also when the category is only weakly linked to the prevailing organisational identity. An organisation may entertain opportunistic reasons to seek membership in a category that is currently not strongly embedded in the organisation's self-understanding. This may happen when an organisation seeks to position itself in a high-status category (Brankovic 2018) but may also involve opportunistic resource-seeking behaviour whereby university leadership seeks to (re-)position the institution so as to affect the judgement and actions of a key audience. As recognised in the literature on organisational path dependency (Sydow et al. 2009), opportunistic strategic actions, such as positioning an organisation in relation to an established category, may over time lead to deeper, potentially irreversible change. In this case, it is possible that an organisation making successful aspirations for membership in a category eventually becomes closely entrenched in that category.

Research on higher education institutions has documented institutional inertia connected to strong institutional identity as well as isomorphic pressure from strong institutional templates and tendencies to react to stakeholder signals by means of positioning work (Stensaker and Norgård 2001; Huisman et al. 2002; Fumasoli and Huisman 2013). While this research does not explicitly discuss organisational categories, it is natural to move from these findings to an 
expectation that HEIs may exhibit both strong and weak forms of ties between organisational self-understanding and aspirations towards category memberships.

Against the view of relationships to categories being shaped reciprocally with organisational identity and history, considering the role of imprinting is a reasonable approach. Following Marquis and Tilscik (2013), we define organisational imprinting as a process whereby, during a brief period of susceptibility, a focal entity develops characteristics that reflect prominent features of the environment, and these characteristics continue to persist despite significant environmental changes in subsequent periods (Marquis and Tilcsik 2013: 199).

\section{To be a technical university}

'Technical universities' may be conceptualised as a category of HEI. The view of technical universities as separable from other types of HEIs has historical roots, tied to polytechnical educational institutions of the type that 'grew up' entangled with the Industrial Revolution and came to prominence in many European countries during the nineteenth century (Fox and Guagnini 2004). This historical distinction is at least partly upheld. One indication of this is that there are networks of HEIs defined by a joint identification as technical universities (e.g. CLUSTER, CESAER, and Nordic5Tech). Moreover, some contemporary ranking systems feature some form of category for technically oriented HEIs. Identification with the category is also driven by many members of the academic staff sharing a strong professional identity as engineers, paralleling their identity as university faculty.

HEIs carrying the appellation 'technical university' (a.k.a. 'institute of technology') play an important role in the European academic landscape. Such institutions are typically focused on engineering science and engineering education, although they are sometimes also home to significant activities within other scientific areas. They are embedded in a tradition of application-oriented research and education, disciplinary development co-produced with technical change, and academic activity in a close relationship with industrial partners. Indeed, for many years, the links to industry were more natural and ingrained in the culture than research was. Over time, the focus in many countries has moved on to research, resulting in modern debates on research drift at technical universities (Harwood 2010) and a rift between research-intensive technical universities and more vocationally oriented polytechnics and universities of applied sciences (Lepori 2008). This distinction may be thought of as an instance of vertical differentiation.

The technical university category in the national context of Sweden involves two dominant actors, both founded in the early nineteenth century: KTH Royal Institute of Technology (henceforth KTH) and Chalmers University of Technology (henceforth Chalmers) (Ahlström 2004; Björck 2016). Engineers have developed a high status in Swedish society, particularly during the twentieth century, playing a key role in the development of a strong industrial sector and a welfare society (Torstendahl 1975). This situation has also deeply affected post-Second World War Swedish higher education policy. Specialised HEIs, such as KTH and Chalmers and the medical university Karolinska Institutet, have long enjoyed a status well in line with that of HEIs modelled as broad research universities (such as Uppsala University and the University of Lund). In this context, the category 'technical university' can thus be described as a type of specialisation that is essentially horizontally differentiated from competing less 
specialised categories and vertically differentiated from institutes of vocational technical training.

\section{Approach}

In our investigation of how actors within HEIs have related to the organisational category 'technical university' in debating, advocating, or resisting organisational or institutional change, we focus on four Swedish HEIs with a substantial orientation towards technical education and research. Based on our own overview of the Swedish institutional setting, we identify an episode in the recent history (1960 and onwards) of each HEI when the identity and formal status of the HEIs (or parts thereof) were subject to negotiation. In doing so, we apply a multiple case study approach (Stake 2005) that follows a theory-centred and comparative design (Thomas 2011). Table 1 presents the four case studies under consideration.

We employ an approach to historical study that Rowlinson et al. (2014) refer to as analytically structured history. This entails narrating theoretically conceptualised structures and events that may or may not have been perceived as such by the actors involved at the time. Furthermore, this approach leads to a focus on historical episodes that are temporally defined through the source material rather than an external historical context. More specifically, we shed light on critical events leading to critical junctures (Sydow et al. 2009) when organisational identity was being mobilised in response to proposed organisational and institutional change in the form of external pressure, internal strategic action, or a combination of both (Covaleski and Dirsmith 1988). We also seek to frame each focal episode by analysing and presenting it in connection with the institutional origins of the HEI and the repercussions (or the lack thereof) of the focal episode until the present.

The study employed a combination of documentary studies (primary and secondary sources) and interviews (oral history) (Lipartito 2014). These written sources include university histories, state committee investigations, news articles, and feasibility and evaluation reports. Table 1 specifies the nature of key source material in each case. For a more complete listing of written material, please see the supplementary online material.

Table 1 Historical cases

\begin{tabular}{|c|c|c|}
\hline HEI & Episode & Key sources \\
\hline $\begin{array}{l}\text { 1. Chalmers } \\
\text { University of } \\
\text { Technology }\end{array}$ & $\begin{array}{l}\text { Discussions concerning a merger with } \\
\text { Gothenburg University 1961-1964 }\end{array}$ & $\begin{array}{l}\text { Historical accords (monographs) about the Uni- } \\
\text { versity of Gothenburg (Lindberg and Nilsson } \\
\text { 1997) and Chalmers, as well as state inquiries }\end{array}$ \\
\hline $\begin{array}{l}\text { 2. Linköping } \\
\text { University }\end{array}$ & $\begin{array}{l}\text { Threats by the technical faculty to break } \\
\text { away and found a new technical } \\
\text { university 1975-1983 }\end{array}$ & $\begin{array}{l}\text { Memoirs of two senior managers, as well as } \\
\text { interviews with three other former senior } \\
\text { managers }\end{array}$ \\
\hline $\begin{array}{l}\text { 3. Blekinge } \\
\text { Institute of } \\
\text { Technology }\end{array}$ & $\begin{array}{l}\text { Renaming from 'university college' to } \\
\text { 'institute of technology' 1997-1998 }\end{array}$ & $\begin{array}{l}\text { Documents submitted to the government by the } \\
\text { HEI applying for a change in status, media } \\
\text { reports, a monograph on the Swedish } \\
\text { university landscape (Andrén 2013), anniver- } \\
\text { sary publications, and interviews with a for- } \\
\text { mer senior manager }\end{array}$ \\
\hline $\begin{array}{l}\text { 4. Mälardalen } \\
\text { University } \\
\text { College }\end{array}$ & $\begin{array}{l}\text { Discussions about a merger with Örebro } \\
\text { University 2004-2008 }\end{array}$ & $\begin{array}{l}\text { Evaluation reports and debate pieces discussing } \\
\text { the proposed merger, media reports, and } \\
\text { interviews with two former and one current } \\
\text { senior manager }\end{array}$ \\
\hline
\end{tabular}


In case studies 2, 3, and 4, elite semi-structured interviews with former and current top managers, rectors, and pro-rectors were undertaken by the authors. Interviewees were asked to comment on the episodes in which they played key roles at the time. These interviews, 45-150 min each, complemented and deepened our understanding. However, interviews of this kind should be treated with caution and appropriate source criticism. Since the interviewees were asked to reflect upon events that happened quite a while ago, their memories might have deceived them. Another critical observation is that the interviewees gave their version of the story, which could undoubtedly be interpreted and even contradicted by others who were there (Thompson 2017). That said, the persons interviewed in examples 2-4 were open, showed adequate memory, and were willing to contribute to the study (Hoddeson 2006). In total, seven interviews were conducted.

\section{Negotiating organisational categories: four historical cases}

\section{Case 1: Chalmers University of Technology's potential merger with Gothenburg University}

A national committee launched by the Swedish government in 1955 (U55) raised the issue of expanding higher education in the natural sciences. To that point, science education and research had primarily been based at the oldest universities in Lund and Uppsala, with engineering education mainly located at the older technical universities, Chalmers University of Technology and KTH Royal Institute of Technology. Gothenburg University (GU) had been founded in 1891 as a private university college but became a university in its own right in 1954. In Gothenburg, the emerging natural science faculty was confronted with already-existing similar disciplines, including physics, mathematics, and chemistry, at Chalmers. The government argued that these disciplines should be coordinated with Chalmers; thus, from 1957 on, GU students were permitted to take courses at Chalmers. In 1961, the natural sciences formally broke away from the GU philosophy faculty, and in 1964, the first science professors were inaugurated. This organisational separation took place simultaneously at all Swedish HEIs.

The greatest challenge for the newly created Faculty of Sciences was the relationship with Chalmers. The teaching was led by academic staff from Chalmers, requiring cross-institutional coordination. Early on, calls for further collaboration and even organisational integration in the form of a merger were heard. The then-ongoing state committees and inquiries all argued for further integration, as did the responsible minister at the time. Attaining economies of scale was the main rationale, primarily in the form of reduced costs for machinery, infrastructure, and administration. Attractiveness was another reason given; joint departments for chemistry, physics, theoretical physics, and mathematics would enable larger research groups with greater possibilities to specialise, which in turn would improve the recruitment of researchers, it was argued. Some internal actors, including a mathematics professor at GU, proposed even further integration in the form of a common administration and a joint board (konsistorium).

However, the joint forces of academic staff and students at Chalmers put an end to all further plans for closer integration and an eventual merger. The rationale was primarily 'cultural', according to Lindberg and Nilsson (1997: 13): 'The motives were complex but were ultimately about defending their own identity.' Chalmers was the older of the two institutions, with a history going back to 1811: 'It was a technical university with another 
culture than the usual academic and an emphasis on practical application and close contacts with business life.' Chalmers had a very active student union harbouring traditions like the annual cortege at Walpurgis and student plays. These traditions, 'irrational but important', according to Lindberg and Nilsson (1997: 13), were considered seriously imperilled by a merger. When the merger was proposed, the vice-chancellor and other senior managers at Chalmers threatened to resign.

The outcome was a compromise. The main message was that the integrity and identity of Chalmers should remain untouched. Joint departments were created but monitored by the Chalmers vice-chancellor and staffed with technical-administrative personnel from Chalmers. The science faculty remained a separate unit at GU, responsible for the curriculum but housed in Chalmers' facilities. The GU students were not represented in any formal fora. While this construction seems to have worked, it also resulted in a slightly 'remote' relationship with the rest of the university. One of the more practical challenges was the annual rhythm of courses and programmes, which differed across the two institutions. Another was the fact that the two institutions used different pay scales.

The idea of a merger between the two Gothenburg sets of learning was reintroduced in the 1970s as part of the comprehensive higher education reform of 1977, founded on a central planning, bureaucratic perspective. The resistance was equally strong in this later instance. This concluding sentence from the History of Gothenburg University summarises the response from Chalmers: 'But there is a continuity in the eagerness for independence, which confirms that Chalmers represents its own tradition and culture which is different from the primarily academic in the university world' (Lindberg and Nilsson 1997: 14). Chalmers and GU remain independent institutions to this day. Starting from the early 2000s, however, the two universities have had a close relationship with a shared organisation in the area of IT located at a separate campus.

\section{Case 2: Linköping Technical Faculty's threatened breakaway from the university}

Linköping University (LiU) was inaugurated in 1975. The new university was organised into three faculties: the technical faculty, the medical faculty, and the philosophy faculty for the social sciences and humanities. Of these three, the technical faculty was arguably the most prestigious. Tertiary-level engineering education had been established in the city almost 10 years before the foundation of the university, with an independent engineering university unit in place since 1969. Even then, Linköping had been allowed to award the degree of civilingenjör (Master of Engineering) to students following a nine-semester engineering programme - an honour that was shared nationally with the two oldest and most prestigious universities in the country (Uppsala University and the University of Lund) and with the two technical universities in Stockholm (KTH) and Gothenburg (Chalmers). The young university even offered two unique, newly created civilingenjör programmes not to be found at any of the other four HEIs. Consequently, the educational programmes at the technical faculty attracted students at the national level, while many of the other educational activities at LiU largely recruited students on a regional basis.

Not long after LiU's foundation, tensions emerged between the technical faculty and the leadership. Arguing that engineering education was of particular national importance and the raison d'être for the political decision to establish higher education in Linköping, voices from within the technical faculty demanded the establishment of a full-time rector and an administrative body of its own. However, the university leadership largely rejected these demands. A 
separate faculty board for the technical faculty was put in place in 1977 but was never given much power. After unsuccessfully pleading to the university board to strengthen the level of delegation to the faculty board, Dean Erlander and Pro-Dean Johannesson threatened to resign from their positions in 1981. As frustration grew, speculation about a possible breakaway by the technical faculty to form a third institute of technology alongside KTH and Chalmers intensified.

For proponents of greater (or total) independence from the other two faculties in LiU, comparisons with KTH and Chalmers formed a key argument. It was argued that engineering education was too important to risk being subjected to internal university resource prioritisation. Furthermore, as the argument went, it was crucial for the recruitment of students to engineering education in Linköping to develop an institutional identity that could match that of the two leading technical institutes. Discussions about the autonomy of the technical faculty came to a halt in 1983 when the faculty board officially declared that it was not striving for the establishment of an independent organisation. Knuthammar (1994) argues that this position was at least partly related to a nationwide drop in student interest in engineering education during the early 1980s, which may have been seen as potentially affecting the balance of power and budgetary strength between faculties. Moreover, Dean Erlander was appointed vice-chancellor of LiU in the fall of 1983 - a post that he was to keep for 12 years. This marked the end of any serious discussion about the technical faculty breaking away and creating a third technical university in Sweden. In the process of negotiation, however, the technical faculty board had already been granted budgetary independence in 1982. For more than 3 decades, the technical faculty operated and marketed itself under the name Linköpings Tekniska Högskola (Linköping Institute of Technology, LiTH). Only in the late 2000s was the name changed to Tekniska Högskolan vid Linköpings Universitet (Institute of Technology at Linköping University) in a move to strengthen the brand identity of LiU among stakeholders as a comprehensive university.

\section{Case 3: Blekinge Institute of Technology's choice of a new name}

In 1989, a new university college was inaugurated in the province of Blekinge: University College Karlskrona/Ronneby. The college was rather strongly profiled towards a focus on applied ICT. A research group in signal processing brought in from the technical faculty of Lund University (which branded itself Lunds Tekniska Högskola) by founding rector Per Eriksson formed an initial basis for the college's ambition to establish itself as a strong environment in a rapidly expanding field. Although it was not well aligned with the historical industry structure of the region, this profile found support among actors from industry, at the municipal level, and from the national government. This support enabled further inflow of funds to build up ICT research.

Based on its positive track record, the university college submitted a request to the government in 1997 for the right to employ full professors and award doctoral degrees in engineering science. These rights were granted in 1998. The government also approved a request to change its name to Blekinge tekniska högskola (BTH), which reflected the new status as equal to universities in terms of rights - if not in resources - within the technical domain. This change, however, was controversial and somewhat paradoxical since Karlskrona/ Ronneby was in the process of merging with the local university college for nursing education. One board member, who represented the county, was openly critical to the decision regarding the name, which she feared would make it more difficult to attract nursing students. The 
initiative for the change came from the rector, who argued that being branded as a technical institute would facilitate recruitment of academic staff and help the university college develop its profile as a focused ICT university.

In the late 1990s, the newly named technical institute was still rather strongly focused on ICT - in terms of research activity in particular. This did not stop the institute from applying to the government yet again in 2002, this time for a formal promotion from 'technical institute' to 'technical university'. In doing so, BTH followed the precedent of Luleå Technical University, which had been granted the name 'Luleå tekniska universitet' along with full university status in 1996. The application would have allowed BTH the right to award doctoral degrees in non-technical subjects as well and was clearly motivated by the ambition to expand the research portfolio in non-technical subjects. Hence, BTH's bid to become a technical university represents an attempt to leverage its strengths in technical research to win status as a full university. However, after a 4-year hiatus, the application was turned down, and BTH formally remains a university college today.

\section{Case 4: Mälardalen University College and the merger that did not happen}

By 2004, Mälardalen University College (MdH) was the largest university college - in terms of research spending - that had not been awarded full-university status in Sweden. MdH had been founded in 1977 as a general university college focused on satisfying the educational needs of its region. However, its research profile was strongly oriented towards technical subjects, with particular strengths in ICT research and robotics, which matched the advanced specialisation of regional industry. This was the outcome of successful recruitment in technology and to funding opportunities. The first professor was appointed in 1997, while the right to award the civilingenjör was granted in 2002. Reflecting this situation, the national authorities granted $\mathrm{MdH}$ the right to award $\mathrm{PhD}$ degrees in engineering but not in other disciplines. Although two-thirds of its research was directed towards engineering and the natural sciences, only two out of five students were enrolled in courses within these domains. Thus, $\mathrm{MdH}$ at that time might be described as a competent technical institute hosting a substantial proportion of non-technical education. These imbalances in the early 2000s were further strengthened by a national downward trend in student interest in technical degrees following the burst of the dot-com bubble.

At this time, the leadership at $\mathrm{MdH}$ emphasised the strategic direction of applying for the right to award degrees in the social sciences, thus obtaining additional funding for social science research and better balancing the academic profile of the university college. Obtaining full university status was seen as both a means and an end in this endeavour. However, it was increasingly obvious to the $\mathrm{MdH}$ leadership that the government was not favourably disposed to changing the status of university colleges to full universities.

It was within this policy context that $\mathrm{MdH}$ began to seriously consider a merger with Örebro University (OrU). The initiative for discussions of collaboration between the two HEIs came from the top academic leaders. An external enquiry, commissioned by the rectors, reported positive reactions among department heads and managers at both HEIs in response to suggestions of a full merger. The report from this enquiry argued that 'a merger between Örebro and Mälardalen could lead to stronger research and education environments, both nationally and internationally. Internationally stronger academic environments could be created within a number of areas, where synergies and increased critical mass could be reached. 
This will lead to reduced vulnerability and increased flexibility, enabling a joint regional provision of education with both breadth and depth' (Taube 2004: 2, our translation).

A follow-up report, written by researchers from the Swedish Institute for Studies in Education and Research, evaluated the potential for a full merger much less optimistically, identifying a strengthened profile as a technical university as a preferable alternative. Hence, the debate around MdH's merger plans came to touch upon essential questions about the preferable option: a more narrowly profiled 'technical institute' or the move towards an organisation mirroring a traditional comprehensive university. The main arguments raised against a merger involved concerns that $\mathrm{MdH}$ risked losing its strong commitment to applied problem-solving and its strong relationship with (locally based) industry if merged with OrU, which was presented as representing an 'ivory tower' approach to research and education. Few of the leading technical researchers saw any potential gain from a merger with OrU; instead, they proposed a stronger collaboration with KTH in Stockholm. More direct opposition to the plans came from MdH's regional stakeholders. In particular, representatives for the region's industrial base raised concerns about a merger threatening to harm established relationships between their firms and the leading technical research environments at $\mathrm{MdH}$.

In view of the internal resistance and uncertainty about whether a merger would receive political support (and, in particular, pave the way for increased state funding), the boards of $\mathrm{MdH}$ and $\mathrm{OrU}$ opted for a wait-and-see strategy that included the allocation of 30 million Swedish kronor to what was referred to as a 'joint effort' in five selected research areas. Only one of these areas (robotics) was within the field of engineering science. In the spring of 2007, it was clear that neither the central government nor the regional administrations were in favour of the kind of merger the proponents had wanted. Thus, a decision to form a 'university federation', to which three further HEIs of small or intermediate size were invited, replaced the merger plans. However, this decision was overturned in November 2008. The then MdH rector declared that the government's recent research bill made it perfectly clear that no further research funding would be made available to the new federation, and that introducing an extensive reorganisation of the HEIs under those conditions was not sufficiently attractive.

In an interesting recent development, MdH's aspirations to be recognised as a full university were renewed when Social Democratic Party leader Stefan Löfven declared during the 2018 election campaign that his party wanted to make $\mathrm{MdH}$ a technical university. After complicated post-election negotiations, Löfven was able to form a government in 2019. At $\mathrm{MdH}$, steps were taken to align the HEI's profile with the idea of being 'promoted' to a 'technical university', with a particular ambition to profile its (non-technical) educational programmes towards technology. In December 2020, however, the social democrat minister for higher education announced that the government had decided to change the status of $\mathrm{MdH}$ from university college to full university. No reference to 'technical university' was made in this decision, which was presented as the fulfilment of a pledge to make $\mathrm{MdH}$ 'a [full] university'.

\section{Discussion}

What do our four historical cases reveal about if and when it has been of interest for an HEI to place itself in the organisational category 'technical university' (TU)? In answering this question, we must first ask to what extent actors may refer to the category 'technical university' as having inherent value. 


\section{The TU category as a signifier of cultural differences}

In our historically earliest case, issues of organisational identity as a concern for academics themselves come to the fore. When the responsible minister was pushing for Chalmers, a technical university, to merge with neighbouring Gothenburg University in the 1960s, Chalmers resisted. Chalmers' identity was perceived as partly at odds with attributes associated with the organisational category 'traditional university', in this case represented by Gothenburg University. Chalmers' identity as a technical university prevailed.

However, the two cases of more recent development at aspiring HEIs offer weaker indications that academic staff saw a move towards being an independent and profiled technical university for the sake of identity per se as important. Neither do we find any signs that concerns about the future recruitment of academic staff were raised. However, arguments about recruitment opportunities are found in reference to the two university colleges' ambitions to obtain status as full universities. In these cases, advancement in institutional hierarchies (moving between vertically differentiated categories) is clearly perceived as more relevant than horizontal institutional differentiation.

Moreover, we find indications that external actors may attribute value to an HEI being positioned as an independent technically oriented university rather than a 'traditional university'. Specifically, industry-based actors may perceive the attributes and cultural expressions associated with a technical university as superior to those associated with a traditional university. An expression of such interests is perhaps most clearly found in the case of MdH's proposed merger with OrU. Key local industrial partners of MdH considered the move to become a university by merging with an HEI in a different region as a threat to relationsperhaps particularly so because OrU was perceived as aspiring to be a 'traditional' university with certain ivory tower connotations (Broström et al. 2005).

\section{Strategic category positioning}

With external actors attaching value to organisational categories, relating to categories in externally oriented communication also becomes strategically beneficial to HEIs. In our cases, evidence suggests that positioning the HEI within the category 'technical university' is used instrumentally to achieve a favourable assessment in the eyes of key external stakeholders, e.g. by triggering associations to attributes and status.

Alumni and - perhaps more acutely important to an HEI - prospective students may attribute value to the HEI being positioned in a horizontally differentiated organisational category such as 'technical university'. We find the most clear-cut example of student-related concerns being raised in the case of the LiTH independence campaign of the late 1970s and early 1980s (case 2). Proponents argued that when competing for student interest for the most prestigious (i.e. longest) engineering programmes (those awarding the title civilingenjör) at the national level, it would be advantageous for the challenger Linköping to be recognised as a technical university of the same type as incumbents KTH and Chalmers. This association between a category of education and a category of educational institution echoes throughout the cases of the aspiring HEIs MdH and BTH but plays a less emphasised role in the key discussions described in these cases.

As is the case in other European countries, Swedish universities are directly dependent on the state for funding and regulation of their activities. Reflecting this dependence, we have found recurring references to contacts with the government and its representatives in our 
empirical studies. In the Linköping case, it is clear that the proponents of engineering faculty independence perceived the political sphere as supportive of engineering education as a national priority and, therefore, as an ally in relation to other interests within the university. In the cases of $\mathrm{MdH}$ and $\mathrm{BTH}$, orientation towards status as a 'technical university' has been leveraged in relationships between the HEI and the government (Andrén 2013). For these aspiring HEIs, adherence to the category 'technical university' seems to have primarily been used instrumentally when seeking support for a shift in formal status from 'university college' to 'university'. Both HEIs had a relatively well-developed technical profile but lacked broader research activity. Therefore, it was seen as more feasible to make a case for being recognised as a technical university than a university 'proper'. That did not, however, imply a general strategy to avoid engaging in non-technical education and research. In other words, the category technical university seems to have been primarily attractive in offering a path for moving away from a hierarchically inferior category ('university college') to that of 'full university'.

\section{Imprinting and ability to change}

Earlier research has shown that the structural and cultural features adopted during the foundation and early years of an organisation tend to be highly stable and persistent over a long period of time (Marquis and Tilcsik 2013; Scott 2013), not least for such slow-moving organisations as universities (Kosmützky and Krücken 2015; Oertel and Söll 2017). As Suddaby and Foster (2017: 21) noted, 'A clear implication of imprinting research is that the historical conditions at founding severely limit an organization's ability to change. History constitutes an objective reality that episodically fixes organizational conditions and constrains the agency of managers who seek to change the organization.' Our study of how HEIs relate to the category 'technical university' elucidates how the imprinting of an organisation at least partially happens through identification with a particular category, from which attributes and status for a new organisation are derived. This is clearly evident in the case of Chalmers, where the enduring, distinct organisational identity of Chalmers as a technical university shaped the institutional response to a proposed merger. In the Linköping case, the technical faculty's origin as an independent organisation was important for engineering academics when threatening to break away from the multi-faculty LiU. Formed in the organisation's early years, its distinct character - in relation both to the other faculties in LiU and to other technical universities - came clearly to the fore in the negotiations with university leadership.

\section{The emergence of a global hegemonic category}

Considering the cases together leads to an overall impression that, over time, it has become less attractive for an aspiring HEI to position itself as a technical university. This observation can, in part, be explained by an overall weakening of the logic by which the TU category was important as a means of appealing to students as well as the central government. After a 2008 reform, the formal distinction between a university college and a university was loosened. Any HEI was now allowed to apply for the right to award doctoral degrees in areas where they had significant research activity, and the dimensioning of research funds following educational volumes was made equal for all HEIs (instead of favouring full universities). In this period, ambitious university colleges removed the term 'university college' from the English version of their name. For example, MdH adopted the name 'Mälardalen University' in its 
international branding and communication. These developments marked an end to a decade-long period of pushing for institutional promotion up the (vertical) category hierarchy among smaller HEIs.

In parallel, legislation introduced in 2007 implemented the European Bologna agreement across Swedish higher education. This development meant that all existing advanced degrees, such as civilingenjör, were formally integrated into a structure where all advanced-level higher education was expected to grant a European Master-degree (Heinze and Knill 2008; Enders and Westerheijden 2014). While this prestigious title is still being used, the introduction of an educational system more strongly harmonised to emphasise vertical differentiation between degrees can be said to have further encouraged organisational differentiation in the vertical rather than the horizontal dimension.

The governmental reforms mentioned above can be understood as reflecting a general movement that began in the 1980s, whereby attention within European higher education gradually shifted towards vertical differences between HEIs (Bleiklie 2005) with a discussion of 'academic drift' (Neave 1979). ${ }^{1}$ The 'world-class university' emerged as a dominant ideal (Salmi 2009; Shin and Kehm 2012). In parallel to the Bologna process for higher education, the introduction of performance-based funding schemes for research also contributed to further emphasis on vertical differentiation between universities (Teichler 2008; Musselin 2018). In this climate, it is not surprising that aspiring HEIs, like MdH and BTH, would seek to carve out their own niches rather than adhering to such existing templates as the engineering-dominated technical university. The category TU remains relevant to them, perhaps primarily from an instrumental point of view. Newly emerging categories, e.g. based on rankings, formal classifications, or voluntary status-enhancing alliances, chiefly serve the purpose of more finely grained vertical differentiation (Musselin 2018).

We may understand the development as a shift towards the broad, research-intensive university becoming a hegemonic category in European higher education. That is, the stakeholders of contemporary HEIs broadly agree that aspirations for development are to be focused on moving towards this organisational template. HEIs such as $\mathrm{MdH}$ may find it beneficial to seek recognition as a 'technical university', considering that the category 'broad university' is not quite within reach (due to insufficient research resources in non-technical disciplines). Yet, very few smaller HEIs aspire to disciplinary specialisation per se. That is not to say, however, that all contemporary HEIs have similar profiles, niches, and aspirations (Teichler 1988; Paradeise and Thoenig 2013). Orphan (2020) argues that many US regional colleges are less prone to prestige-seeking behaviour than what is often assumed in the higher education debate, cherishing the mission of regional access to postsecondary education. In the oldest and most prestigious institutions traditionally associated with a category of specialisation such as 'technical university', the social order that grants them status and incumbency may be treasured (Podolny 2010; Brankovic 2018).

\section{Conclusion}

In this paper, we have discussed how the expression and renegotiation of organisational identities are shaped by key actors' interpretation and active mobilisation of organisational categories. Four examples were selected to show how different arguments relating to the

\footnotetext{
${ }^{1}$ See Gonzales (2013) for a related view from the USA.
} 
relevance of 'technical university' (TU) as an organisational category were used to champion or resist proposed organisational restructuring. In two of the cases, proposed mergers aiming to establish broad universities ultimately failed to take place. Only in the oldest of these cases, however, was the preservation of organisational identity as a focused TU brought forward as a central argument against a merger. A third case shows how positioning an aspiring university college as a TU through a name change was perceived as making the institution more attractive to potential students and academic staff. In a further case, a technical faculty sought to ensure its organisational independence and even considered breaking away from the comprehensive university. Overall, our approach has provided an analysis of how identification with one or another organisational category shaped the intentions of key actors and offered important points of reference for boundary work. Specifically, ideas about the categories 'technical university' and 'university' were shown to have shaped attitudes and behaviours towards internal and external pressures for changes in organisational structure.

Our analysis of cases at four Swedish HEIs shows how in two cases from the 1960s and early 1980s, engineering faculty perceived it as attractive for their institution to remain and become, respectively, an independent 'technical university'. We also show how positioning an HEI as a technical university has been perceived as providing important benefits in externally oriented relationships. Specifically, the positioning of an HEI in relation to the organisational category technical university was relevant in relation to prospective students and to the state in the context of negotiations about resources and degree awarding rights. For the two aspiring HEIs, however, the TU organisational category was primarily mobilised as a feasible step where full inclusion in the hegemonic category was not quite possible, rather than as a desired organisational template. That is, aspiring HEIs have not strongly or actively sought to adjust their boundary work so as to move closer to the ideal of a focused technical university. Furthermore, our impression is that all of the aspects that were identified as making it attractive to identify as a technical university have weakened over time. Since the late 2000s, the broad 'world-class university' has come to constitute a global hegemonic category, against which other categories are perceived as inferior (Salmi 2009; Hazelkorn 2015). We discuss how this has even become the case in a country where the traditional technical universities have had a dominant role. We argue that while Sweden's two incumbents with a long history of being the most prestigious actors in this category largely remain committed to being technical universities, such aspirations are less relevant for younger HEIs.

The paper contributes to research on the organisational identity of HEIs (Stensaker 2015) and on universities as strategic and responsive actors (Krücken and Meier 2006; Thoenig and Paradeise 2016; Pinheiro and Stensaker 2015). Most of the earlier studies in this field have discussed the progression of younger institutions to full university status and the academic drift taking place in binary systems with universities and polytechnics (Kyvik 2008). In other words, where earlier research has investigated how HEIs relate to competing and partly overlapping organisational categories, the focus has almost exclusively been placed on vertically differentiated categories forming an institutional hierarchy (Gonzales 2013; Fumasoli et al. 2019). This paper explores the relevance of the 'technical university' as an organisational category. This category is defined in terms of specialisation, and as such, it is horizontally differentiated from competing categories relevant to HEIs, such as 'comprehensive university', 'traditional university', and 'full-fledged university'.

The paper also responds to the call for more studies examining the recent history of organisations and contributes to a recent stream of scholarship demonstrating how a historical consciousness enables a wider perspective on change in complex organisations (Bucheli and Wadhwani 2014; Suddaby 2016; Maclean et al. 2021). We highlight the role of organisational 
categories as reference points for the development of organisational identity in HEIs and, thereby, for organisational responses to external impulses. Our study aligns with recent research on the historical roots of HEIs showing that the structural and cultural features adopted during the foundation and early years of an organisation tend to be highly stable and persistent over a long period of time (Kezar and Eckel 2002; Kosmütsky and Krücken 2015; Oertel and Söll 2017). Organisational imprinting also importantly shapes the image of an organisation and its ability to change (Scott 2013). Contributing to this line of research, we illustrate how organisational imprinting of higher education institutions comprises an important element of association between the new organisation and existing organisational categories and templates. For example, a new engineering education institution established in the Swedish higher education landscape of the 1970s was imbued with contemporary ideas about what constitutes desirable and 'proper' characteristics of an 'institute of technology'. Thereby, the organisational identity and self-understanding of such an HEI are tied to that category. This tie would tend to be stronger for categories associated with high status than for other categories (Brankovic 2018).

Recognising the role of organisational categories in the imprinting of HEIs opens up a new perspective on the role of imprinting for organisational change. Whereas imprinting research has emphasised how the historical conditions at founding severely limits an organisation's ability to change, the perspective of imprinting as involving an important element of association to a widely recognised organisational category suggests a radically different way to think about the consequences of imprinting. For an HEI associated with a category of specialisation through organisational imprinting, changes in the attributes and relative status of that category may induce change. For example, if perceptions about what it entails to be a technical university changes, or if perceptions change about the relative status of being a technical university (e.g. in relation to being a 'broad research university'), the HEI that is used to thinking of itself and presenting itself as a technical university may be led to reconsider its strategic priorities. Accordingly, imprinting becomes a driver of change rather than inertia. Further research should investigate this conjecture.

Supplementary Information The online version contains supplementary material available at https://doi.org/ 10.1007/s10734-021-00757-w.

Funding Open access funding provided by Royal Institute of Technology. This research was funded by the Riksbankens Jubileumsfond (Grant No. SGO14-1247:1)

Open Access This article is licensed under a Creative Commons Attribution 4.0 International License, which permits use, sharing, adaptation, distribution and reproduction in any medium or format, as long as you give appropriate credit to the original author(s) and the source, provide a link to the Creative Commons licence, and indicate if changes were made. The images or other third party material in this article are included in the article's Creative Commons licence, unless indicated otherwise in a credit line to the material. If material is not included in the article's Creative Commons licence and your intended use is not permitted by statutory regulation or exceeds the permitted use, you will need to obtain permission directly from the copyright holder. To view a copy of this licence, visit http://creativecommons.org/licenses/by/4.0/.

\section{References}

Ahlström, G. (2004). Technical education, engineering, and industrial growth: Sweden in the nineteenth and early twentieth centuries. In R. Fox \& A. Guagnini (Eds.), Education, technology and industrial performance in Europe 1850-1939 (pp. 115-140). Cambridge University Press. 
Andrén, C. G. (2013). Visioner, vägval och verkligheter: Svenska universitetens utveckling efter 1940. [Visions, route selection and realities: The development of Swedish universities after 1949] Lund: Nordic Academic Press.

Augier, M., \& March, J. (2011). The roots, rituals, and rhetorics of change: North American business schools after the Second World War. Stanford University Press.

Bennis, W. G., \& O’Toole, J. (2005). How business schools have lost their way. Harvard Business Review, 83 (5), 96-104.

Björck, H. (2016). A distinguished scientific field? Pursuing resources and building institutions for engineering research in Sweden, 1890-1945. History and Technology, 32(4), 315-348. https://doi.org/10.1080/ 07341512.2016 .1274174

Bleiklie, I. (2005). Organizing higher education in a knowledge society. Higher Education, 49(1-2), 31-59.

Brankovic, J. (2018). The status games they play: Unpacking the dynamics of organisational status competition in higher education. Higher Education, 75(4), 695-709.

Broström, A., Deiaco, E., \& Melin, G. (2005). Vägval för Örebro universitet och Mälardalens högskola: utredning av förutsättningar för fusion, allians eller annan samverkan. [Örebro University and Mälardalen University at the Crossroads: An investigation of preconditions for merger, alliance or other cooperation] Stockholm: Institutet för studier av utbildning och forskning.

Bucheli, M., \& Wadhwani, R. D. (2014). Organizations in time. Oxford University Press.

Covaleski, M. A., \& Dirsmith, M. W. (1988). An institutional perspective on the rise, social transformation, and fall of a university budget category. Administrative Science Quarterly, 562-587.

Deephouse, D. L. (1999). To be different, or to be the same? It's a question (and theory) of strategic balance. Strategic Management Journal, $20(2), 147$.

Eckel, P. D. (2008). Mission diversity and the tension between prestige and effectiveness: An overview of US higher education. Higher Education Policy, 21(2), 175-192.

Enders, J., \& Westerheijden, D. F. (2014). Quality assurance in the European policy arena. Policy and Society, 33 (3), 167-176.

Fox, R., \& Guagnini, A. (2004). Education, technology and industrial performance in Europe 1850-1939. Cambridge University Press.

Fumasoli, T., Barbato, G., \& Turri, M. (2019). The determinants of university strategic positioning: a reappraisal of the organisation. Higher Education, 1-30.

Fumasoli, T., \& Huisman, J. (2013). Strategic agency and system diversity: Conceptualizing institutional positioning in higher education. Minerva, 51(2), 155-169.

Gioia, D. A., Patvardhan, S. D., Hamilton, A. L., \& Corley, K. G. (2013). Organizational identity formation and change. The Academy of Management Annals, 7(1), 123-193.

Glynn, M. A., \& Navis, C. (2013). Categories, identities, and cultural classification: Moving beyond a model of categorical constraint. Management Studies, 50(6), 1124-1137.

Gonzales, L. D. (2013). Faculty sensemaking and mission creep: Interrogating institutionalized ways of knowing and doing legitimacy. The Review of Higher Education, 36(2), 179-209.

Harwood, J. (2010). Understanding academic drift: On the institutional dynamics of higher technical and professional education. Minerva, 48(4), 413-427.

Heinze, T., \& Knill, C. (2008). Analysing the differential impact of the Bologna Process: Theoretical considerations on national conditions for international policy convergence. Higher Education, 56(4), 493-510.

Hoddeson, L. (2006). The conflict of memories and documents: Dilemmas and pragmatics of oral history. In R. E. Doel \& T. Söderqvist (Eds.), The historiography of contemporary science, technology, and medicine: Writing recent science (pp. 187-200). Routledge.

Hazelkorn, E. (2015). Rankings and the reshaping of higher education: The battle for world-class excellence. Palgrave Macmillan.

Huisman, J., Norgård, J. D., \& Rasmussen, J. r. G., and Stensaker, B. (2002). 'Alternative’ universities revisited: A study of the distinctiveness of universities established in the spirit of 1968. Tertiary Education and Management, 8(4), 315-332.

Kezar, A., \& Eckel, P. D. (2002). The effect of institutional culture on change strategies in higher education: Universal principles or culturally responsive concepts? The Journal of Higher Education, 73(4), 435-460.

Knuthammar, C. (1994). En omväxlande historia: Linköpings tekniska högskola 1969-1994. [A Variegated History: Linköping Technical College 1969-1994]. : Linköping University.

Koch, J. (2011). Inscribed strategies: Exploring the organizational nature of strategic lock-in. Organization Studies, 32(3), 337-363.

Kosmützky, A., \& Krücken, G. (2015). Sameness and difference: Analyzing institutional and organizational specificities of universities through mission statements. International Studies of Management and Organization, 45(2), 137-149. 
Krücken, G., \& Meier, F. (2006). Turning the university into an organizational actor. In G. S. Drori, J. W. Meyer, \& H. Hwang (Eds.), Globalization and organization: World Society and organizational change (pp. 241257). Oxford University Press.

Kyvik, S. (2008). The dynamics of change in higher education: Expansion and contraction in an organisational field. Springer.

Lepori, B. (2008). Research in non-university higher education institutions: The case of the Swiss universities of applied sciences. Higher Education, 56(1), 45-58.

Lindberg, B., \& Nilsson, I. (1997). Göteborgs universitets historia. Gothenburg: Gothenburg University.

Lipartito, K. (2014). Historical sources and data. In M. Bucheli \& R. Daniel Wadhwani (Eds.), Organizations in Time: History, Theory, Methods. Oxford University Press.

Maclean, M., Clegg, S., Suddaby, R., \& Harvey, C. (2021). Historical organization studies: Theory and applications. Routledge.

Marquis, C., \& Tilcsik, A. (2013). Imprinting: Toward a multilevel theory. Academy of Management Annals, 7 (1), 195-245.

Meyer, A. G., Hanson, A. R., \& Hickman, D. C. (2017). Perceptions of institutional quality: Evidence of limited attention to higher education rankings. Journal of Economic Behavior \& Organization, 142, 241-258.

Metzger, M. L. (2012). Conflict and change in category identities: How did the internet change what it means to be a travel agent? $\mathrm{PhD}$ Thesis, University of Oregon.

Moodie, G. (2009). Four tiers. Higher Education, 58(3), 307-320.

Musselin, C. (2018). New forms of competition in higher education. Socio-Economic Review, 16(3), 657-683.

Neave, G. (1979). Academic drift: Some views from Europe. Studies in Higher Education, 4(2), 143-159.

Negro, G., Koçak, Ö., \& Hsu, G. (2010). Research on categories in the sociology of organizations. In G. Hsu, G. Negro, \& Ö. Koçak (Eds.), Categories in markets: Origins and evolution (pp. 3-35). Emerald Group Publishing.

Oertel, S., \& Söll, M. (2017). Universities between traditional forces and modern demands: The role of imprinting on the missions of German universities. Higher Education, 73(1), 1-18.

Orphan, C. M. (2020). Not all regional public universities strive for prestige: Examining and strengthening mission-centeredness within a vital sector. New Directions for Higher Education, 2020(190), 9-24.

Paradeise, C., \& Thoenig, J. C. (2013). Academic institutions in search of quality: Local orders and global standards. Organization Studies, 34(2), 189-218.

Pelikan, J. (1992). The idea of the university: A reexamination. : Yale University Press.

Podolny, J. M. (2010). Status signals: A sociological study of market competition. Princeton University Press.

Porac, J. F., Thomas, H., \& Baden-Fuller, C. (1989). Competitive groups as cognitive communities: The case of Scottish knitwear manufacturers. Journal of Management Studies, 26, 397-416.

Rao, H., Monin, P., \& Durand, R. (2005). Border crossing: Bricolage and the erosion of categorical boundaries in French gastronomy. American Sociological Review, 70, 968-991.

Rowlinson, M., Hassard, J., \& Decker, S. (2014). Research strategies for organizational history: A dialogue between historical theory and organization theory. Academy of Management Review, 39(3), 250-274.

Salmi, J. (2009). The challenge of establishing world class universities. The World Bank.

Schreyögg, G., Sydow, J., \& Holtmann, P. (2011). How history matters in organisations: The case of path dependence. Management and Organizational History, 6(1), 81-100.

Scott, W. R. (2013). Institutions and organizations: Ideas, interests, and identities. Sage Publications.

Shin, J. C., \& Kehm, B. M. (Eds.). (2012). Institutionalization of world-class university in global competition (Vol. 6). Springer Science \& Business Media.

Stake, R. E. (2005). Qualitative Case Studies. In N. K. Denzin \& Y. S. Lincoln (Eds.), The Sage handbook of qualitative research (pp. 443-466). Sage Publications Ltd..

Stensaker, B. (2004). The transformation of organisational identities: Interpretations of policies the concerning the quality of teaching and learning in Norwegian higher education. $\mathrm{PhD}$ Thesis. Twente: University of Twente.

Stensaker, B. (2015). Organizational identity as a concept for understanding university dynamics. Higher Education, 69(1), 103-115.

Stensaker, B., \& Norgård, J. D. (2001). Innovation and isomorphism: A case-study of university identity struggle 1969-1999. Higher Education, 42(4), 473-492.

Suddaby, R. (2016). Toward a historical consciousness: Following the historic turn in management thought. M@n@gement, 19(1), 46-60.

Suddaby, R., \& Foster, W. M. (2017). History and organizational change. : Sage Publications.

Sydow, J., Schreyögg, G., \& Koch, J. (2009). Organizational path dependence: Opening the black box. Academy of Management Review, 34(4), 689-709.

Taube, Ö. (2004) Samverkan mellan Örebro universitet och Mälardalens högskola. [Collaboration between Örebro University and University College Mälardalen]. Unpublished report. 
Teichler, U. (1988). Changing Patterns of the Higher Education System. The Experience of Three Decades. Jessica Kingsley.

Teichler, U. (2008). Diversification? Trends and explanations of the shape and size of higher education. Higher Education, 56(3), 349.

Thomas, G. (2011). A typology for the case study in social science following a review of definition, discourse, and structure. Qualitative Inquiry, 17(6), 511-521.

Thompson, P. (2017). The voice of the past: Oral history (4th ed.). : Oxford University Press.

Thoenig, J. C., \& Paradeise, C. (2016). Strategic capacity and organisational capabilities: A challenge for universities. Minerva, 54(3), 293-324.

Torstendahl, R. (1975). Dispersion of engineers in a transitional society: Swedish technicians 1860-1940, : Acta Universitatis Upsaliensis.

van Vught, F. (Ed.). (2009). Mapping the higher education landscape: Towards a European classification of higher education. Springer Science \& Business Media.

Vergne, J. P., \& Wry, T. (2014). Categorizing categorization research: Review, integration, and future directions. Journal of Management Studies, 51(1), 56-94.

Zuckerman, E. W. (1999). The categorical imperative: Securities analysts and the illegitimacy discount. American Sociological Review, 104, 1398-1438.

Publisher's note Springer Nature remains neutral with regard to jurisdictional claims in published maps and institutional affiliations. 